\title{
Design of a new braiding device with 3D integral active yarn carrier
}

\author{
DOI: 10.35530/IT.071.06.1706
}

SONGYIFAN

HEXINHAI

ZHANGZHIYI

LIANGJUNHAO

ZHANGLIANG

\section{ABSTRACT - REZUMAT}

\section{Design of a new braiding device with 3D integral active yarn carrier}

The braided motion of a Cartesian braiding machine is realized by pushing the yarn carriers against each other, which results in the low braiding efficiency, single product and poor expansion at present. A new braiding device three-dimensional (3D) integral active yarn carrier is designed. Firstly, the Integral braiding technology and traditional braiding equipment are analysed. Then an automated guided vehicle (AGV) based active carrier and its braided chassis are designed. A new steering device and power supply system are developed. The braiding process is wirelessly controlled. Finally, it is concluded that the flexible braiding of prefabricated parts of various complex shapes can be realized by the integrated braiding technology of the active yarn carrier through the analysis of the structure and working mode of the active yarn carrier.

Keywords: Cartesian braiding, active yarn carrier, AGV, 3D integrated braiding, flexible braiding

\section{Proiectarea unui nou dispozitiv de împletire cu purtător de fir activ integral 3D}

Mișcarea de împletire a unei mașini de împletit Cartezian se realizează prin împingerea purtătorilor de fir unul spre celălalt, ceea ce are ca rezultat o eficiență scăzută a împletirii, un singur produs și o extindere slabă, în prezent. Este conceput un nou dispozitiv de împletire cu purtător de fir activ integral 3D. În primul rând, sunt analizate tehnologia de impletire integrală și echipamentul tradițional de împletire. Apoi, sunt proiectate un purtător activ bazat pe un vehicul ghidat automat (AGV) și șasiul său împletit. Sunt dezvoltate un nou dispozitiv de direcție și un sistem de alimentare cu energie electrică. Procesul de împletire este controlat wireless. În cele din urmă, se concluzionează că împletirea flexibilă a părților prefabricate de diferite forme complexe poate fi realizată prin tehnologia integrată de împletire a purtătorului de fir activ prin analiza structurii și a modului de lucru al purtătorului de fir activ.

Cuvinte-cheie: împletire Carteziană, purtător de fir activ, AGV, împletire integrată 3D, împletire flexibilă

\section{INTRODUCTION}

The technology of 3D integral braiding is characterized by the capability of braiding the preforms with cross-sectional variations for 3D braided composites, with its technology and equipment, a variety of preforms can be formed at a single net size [1-2]. At present, the chassis track of "four-step" Cartesian braiding machine is mainly divided into sliding type and fixed type. The yarn carriers of braiding machine can be moved by pushing against each other, which are placed into the corresponding position of the chassis manually according to the shape of the preforms before braiding. There is no gap between the driving carriers. Therefore, it takes a lot of work to determine the position of the carriers when braiding multiple varieties of composites preforms [3-6]. The low braiding efficiency of cross-sectional variations preforms is due to manual intervention. The "four-step" braiding technology is limited by traditional braiding equipment, resulting in low efficiency, single product and high cost. Therefore, the research of braiding technology and the development of new equipment are critical.

\section{D INTEGRAL BRAIDING TECHNOLOGY AND PRE-EQUIPMENT}

3D integral braiding technology can be divided into cross-sectional variations and profiled technology [7]. The characteristics of cross-sectional variations braiding technology is to change the number or fineness of yarns involved in the braiding process which do not affect the subsequent braiding process, and then the integral braiding of cross-sectional variations performs is realized [8]. The complex shaped preforms can be braided mainly by profiled braiding technology, such as T-shaped and I-shaped section preforms, which are not braided properly by the traditional "four-step" braiding method as the array of the carrier is different from that of the braided rectangular section. Therefore, the mixed braiding technology is usually adopted for the complex shaped preforms [9].

Automation was difficultly achieved by traditional braiding equipment due to the structural limitation of chassis transmission device. The flexible integral braided chassis device was developed by our research group in early-stage, as shown in figure 1. The motion control card and micro-controller were 
used to control the stepping motor and positioning mechanism and make the yarn carrier move in any row or column. It was suitable for the integral braiding of profiled braiding preforms by a mixed braiding technology. The track structure of the chassis was fixed, which makes it difficult to expand the overall scale. Li utilized an active yarn carrier model with linear stepping motor as self-driving device. The high requirements for track laying, power supply and antielectromagnetic interference were necessary [10].

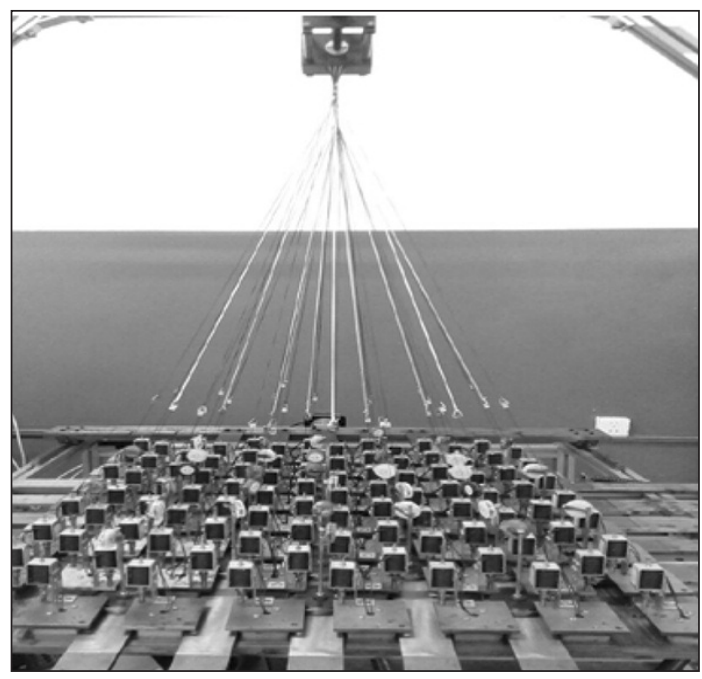

Fig. 1. Flexible integral braiding chassis device

In order to solve the problems of traditional equipment, the active yarn carrier based on AGV technology is proposed, which has the characteristics of simple structure, easy control, good adaptability and modular assembly. The automatic braiding of crosssectional variations and profiled preforms can be realized.

\section{NEW ACTIVE YARN CARRIER AND MATCHED CHASSIS DEVICE}

Structural design of active yarn carrier and its matching chassis

Active yarn carrier and its matched chassis device is shown in figure 2 . The yarn storage device is omitted. It mainly includes active yarn carrier 1 and braiding chassis 2. The double power structure in vertical and horizontal direction with four wheels steering was adopted. Zero radius steering can be realized in row or column braiding motion. The braiding chassis adopts modular design and each module was wired, then assembled according to the size of cross-section of preforms, and providing power and guidance for the yarn carrier. A positioning device is placed at the junction at the bottom of the groove to provide positioning for the carrier. The axis can be arranged at the junction of the gaps between the carriers. The motion of the carrier is controlled by a host computer. The motion state and position of the carrier can be feed backed in real time by the feedback module. The entire braiding process is controlled by automation to reduce manual intervention.

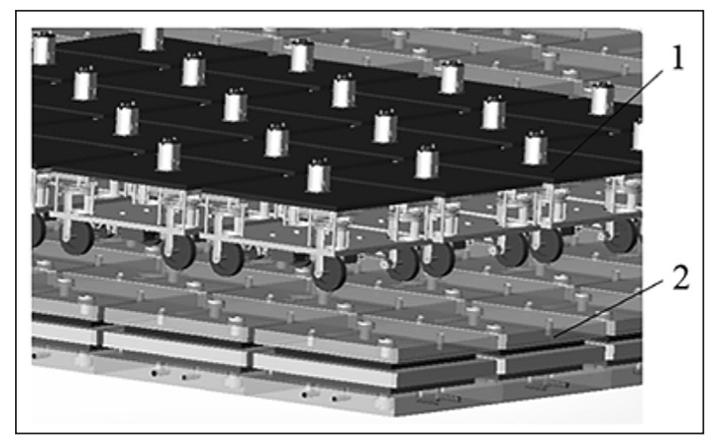

Fig. 2. Active yarn carrier and its matching chassis structure diagram: 1 - active yarn carrier; 2 - braiding chassis

\section{Design of core mechanisms}

The steering device is shown in figure 3 . The original steering and rotation angle of the four bogies are limited by the torsion spring and location pin. For example, the sample is rotated through $90^{\circ}$ by the location pins 8 and 9 , so that the direction of the wheel 10 controlled by the bogie is parallel to the $\mathrm{X}$-axis or the Y-axis. The circular belt 3 is connected to the two bogies on the left and the two ends are respectively fixed by fasteners 1 and 7 in the corresponding positions of the bogies. Similarly, the circular belt 13 is connected to the corresponding positions of the two bogies on the right. In order to prevent the belt from slipping with the steering wheel 5 , the corresponding position is fixed by fasteners 4 and 12 . The steering wheel is rotated $90^{\circ}$ clockwise by the steering motor. Under the action of the torsion spring and the belt, the four bogies are rotated $90^{\circ}$ at the same time, the wheels 7 and 14 are rotated counter-clockwise $90^{\circ}$, and wheels 2 and 10 are rotated clockwise $90^{\circ}$. Then the four wheels are parallel to the $Y$ axis. When the steering motor is rotated counter-clockwise $90^{\circ}$, the four wheels are parallel to the $X$ axis. By fixing the belt on the same steering wheel, the torque of the

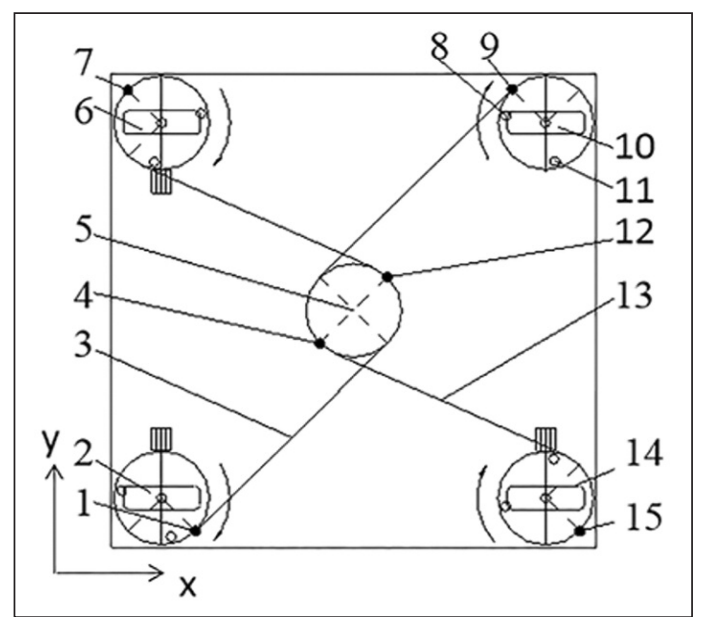

Fig. 3. Schematic views of steering gear: 1 - fastener; 2 - wheel; 3 - circular belt; 4 - fastener; 5 - steering wheel; 6 - wheel; 7 - fastener; 8 - location pin; 9 - fastener; 10 - wheel; 11 - location pin; 12 - fastener; 13 - circular belt; 14 - wheel; 15 - fastener 


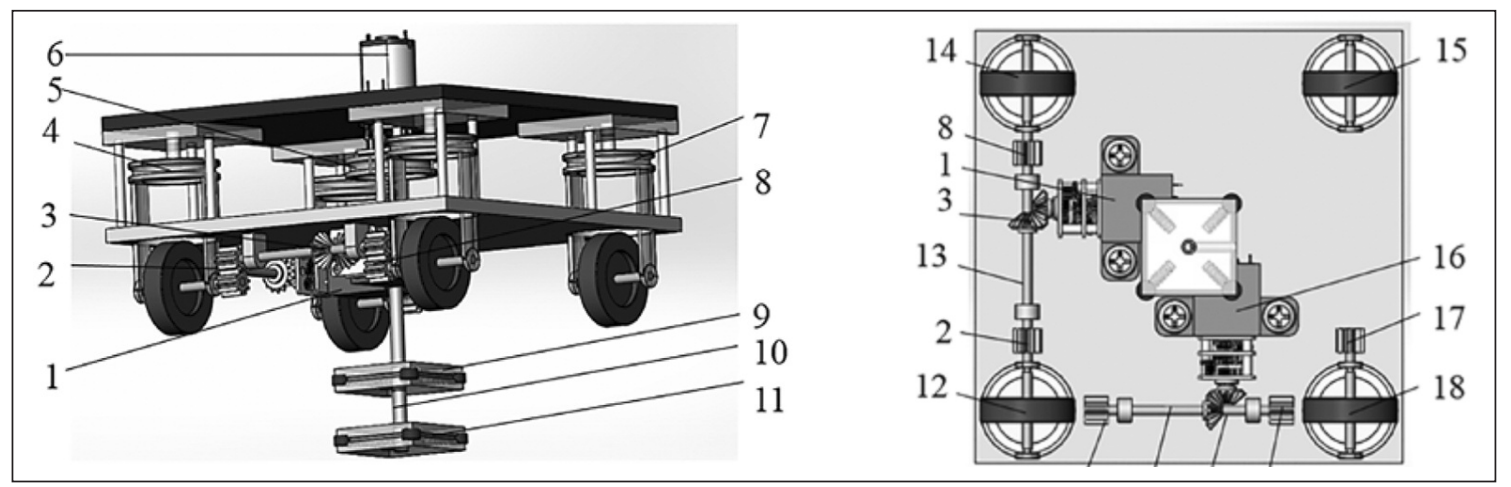

Fig. 4. Structural diagram of active yarn carrier: 1 - gear motor; 2 and 3 - spur gear pair; 4 - steering wheel; 5 -steering wheel; 6 - steering motor; 7 -steering wheel; 8 -spur gear pair; 9 - negative guide block; 10 - shaft; 11 - positive guide block; 12 - wheel; 13 - shaft; 14 - wheel; 15 - wheel; 16 - gear motor; 17 - gear; 18 - wheel; 19 - gear; 20 - bevel gear pair; 21 - transmission shaft; 22 - gear

four torsion springs offset will be created. The dependence on the torque of the steering motor is reduced. The structure of the active carrier is shown in figure 4. In order to improve the stability of the motion of the yarn carrier, the driving system is placed at the bottom. The driving system is composed of two gear motors and mechanical structure. The shaft 13 is driven by the gear motor 1 , and then the wheels 12 and 14 are driven through spur gear pair 2 and 8 . The positive and negative motion of the carrier in the $X$ axis is realized by controlling the positive and negative rotation of the motor 1 . When the steering wheel 5 is rotated $90^{\circ}$ clockwise by the steering motor 6 , the four wheel directions are parallel to the $Y$ axis. The two pairs of gear pairs are constituted by the gears 19 and 22 at the two ends of the transmission shaft 21 respectively. Similarly, the power of wheels 12 and 18 can be provided by the gear motor 16 and the motion of the yarn carrier in the positive and negative directions of the $Y$ axis will be realized.

The guiding and power supply modules are integrated as shown in figure 5 . The row or column movement of the yarn carrier can be guided and the bias caused by the tension of the braided yarn will be avoided. In order to avoid short circuit or open circuit at the intersection of the track, the negative lead 3 on the upper side and the positive lead 4 on the bottom are adopted by the chassis module wiring. A unified

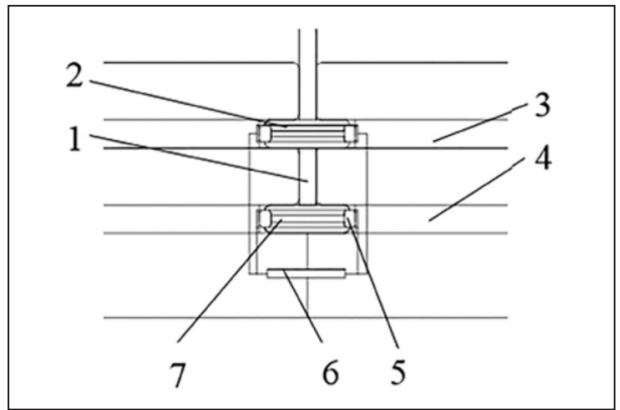

Fig. 5. Guiding and power supply schematic diagram: 1 - connecting rod; 2 - negative guide block; 3 - negative lead; 4 - positive lead; 5 - carbon brush; 6 - wire interface; 7 - positive guide block power supply system for the entire braided chassis can be formed through the wire interface 6 of each module. The carbon brush 5 is embedded in the corners of the guiding and power supply block to ensure that the carrier is kept in contact with the chassis wiring during the movement, and the contact is stable at the row or column crossing positions.

\section{RESULTS AND DISCUSSION}

As the independent driving system of the active yarn carrier, it can move independently or in groups on the braiding chassis. It is suitable for cross-sectional variations and profiled braiding with "four-step" method. The motion of yarn carrier is introduced with the examples of variable cross-section preform braided by unit number reduction method and profiled preform braided by mixed method.

Figure 6 shows the array of the carrier on the chassis when the braiding of the preform is reduced from $6 \times 6$ to $4 \times 4$ mode, and physical picture of preform. Beginning of braiding, the $6^{*} 6$ mode carriers move in groups according to the "four-step" method. When the cross-section of the preform is reduced, the additional carriers are moved from the braiding area to the standby area in the nearest path, and join the braiding area again to continue braiding when the

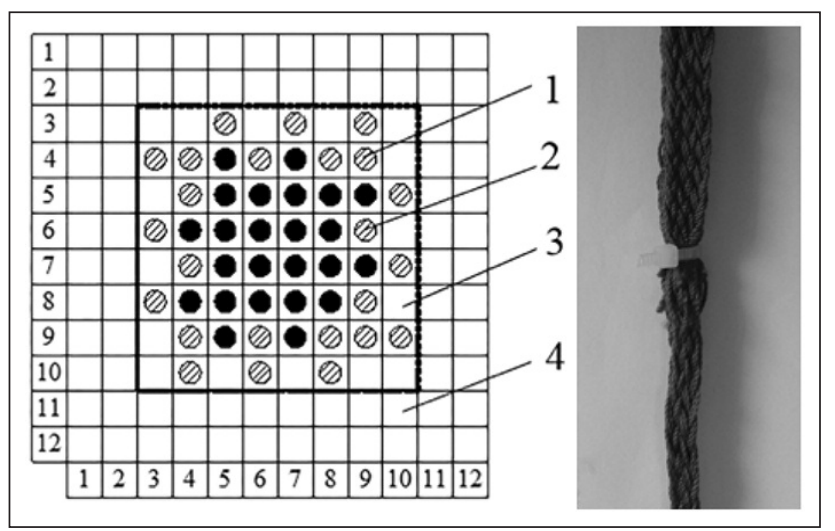

Fig. 6. Reduction of $6 \times 6$ patterns to $4 \times 4$ patterns braided chassis array and resulting braid: $1-$ main carrier; 2 - additional carrier; 3 - braiding area; 4 - standby area 


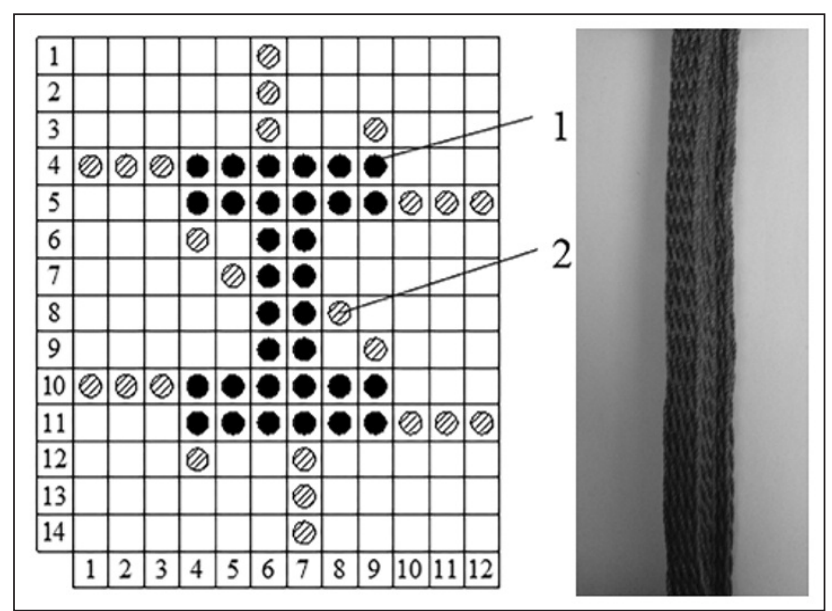

Fig. 7. Chassis initial array diagram of braiding I-shaped fabric $8 \times 6$ patterns and resulting braid: 1 - main carrier; 2 - additional carrier

cross-section is enlarged. At this time, the remaining carriers still are moved according to the "four-step" method. Based on the change of section, the carriers can be controlled to join or exit the braiding area. The braiding area and standby area are determined by the variation of section size.

Figure 7 shows the initial array of the carrier on the chassis when the braiding $8 \times 6$ mode l-shaped preform by using "four-step" method $1 \times 3$ and $3 \times 1$ hybrid pattern, and physical picture of preform. Since each carrier can move independently, without considering the vacancy position. In the first step, the $4^{\text {th }}$ and $10^{\text {th }}$ rows of the carriers move to the right by three positions, the $7^{\text {th }}$ row of the carriers move to the right by one position, and the $5^{\text {th }}$ and $11^{\text {th }}$ rows of the carriers move to the left by three positions. The $8^{\text {th }}$ row of carriers moves to the left by one position number. In the second step, the $4^{\text {th }}$ and $7^{\text {th }}$ column carriers move up one and three positions respectively, and the $6^{\text {th }}$ and $9^{\text {th }}$ column carriers respectively move downwards three and one position number. The third step is opposite to the first step and the fourth step is opposite to the second step. A cycle weaving can be completed by a four-step cycle. It is necessary to design the corresponding control scheme according to the required braiding technology when braiding different performs.

\section{CONCLUSIONS}

In this paper, a new type of active yarn carrier is designed for cross-sectional variations and profiled performs braiding. The integral braiding of performs with various complex shapes can be realized by the self-powered active yarn carrier and assembled braiding chassis through wireless control system, which avoids the problems of single braiding variety and poor expansion of traditional braiding equipment. It can be applied to the braiding of various performs in small batches. The carrier can work longer hours by the chassis wiring power supply mode. The host control signal can be accepted by the wireless control module to achieve independent or group motion on the chassis. It is suitable for 3D integral braiding technology to braid performs with various structures and shapes. The flexibility and versatility of braiding equipment will be improved.

\section{ACKNOWLODGEMENTS}

We would like to express our appreciation to Shaanxi Province's Industrial Science and Technology Tackling Project (Project no: 2020GY-273, 2016GY-014); Xi'an Science and technology projects (Project no: 2019217114GXRC007CG008-GXYD7.3); Shaoxing Keqiao West-Tex Textile Industry Innovative Institute Project (Project no: 19KQZD01) for the financial support.

\section{REFERENCES}

[1] Pastore, C.M., Ko, F.K., Modelling of Textile Structural Composites Part I: Processing-science model for threedimensional braiding, In: The Journal of The Textile Institute, 1990, 81, 4, 480-490

[2] Wang, Y.Q., Wang, A.S.D., On the topological yarn structure of 3-D rectangular and tubular braided preforms, In: Composites Science \& Technology, 1994, 51, 4, 575-586

[3] Sontag, T., Advances in 3D Textiles || Recent advances in 3D braiding technology, In: Advances Ind Textiles, 2015, 153-181

[4] Florentine, R.A., Apparatus for weaving a three dimensional article, U.S. Patent 4312261, 1982, 1

[5] Robert, M., Roberts. 3 dimensional braiding apparatus, U.S. Patent 5,337,647A, 1992, 03

[6] Konrad, L., Krauland. Method and apparatus for braiding three-dimensional fabrics, U.S. Patent 4, 881, 444, 1989,11

[7] Bilisik, K., Three-dimensional braiding for composites: A review, In: Textile Research Journal, 2012, 83, 13, 1414-1436

[8] Liu, Z.L., Yu, J.Y., Research progress in reducing-yarn technique and mechanical properties of $3 D$ braided composites with tapered cross-section, In: Materials Review, 2010, 24, 10, 104-107, 116

[9] Kostar, T.D., Chou, T.W., A methodology for Cartesian braiding of three-dimensional shapes and special structures, In: Journal of Materials Science, 2002, 37, 13, 281-2824

[10] Li, Z.N., Study and design on active yarn carrier's drive applied in 3-D braiding machine, Wuhan Textile University, 2013 
Authors:

SONGYIFAN ${ }^{1,2}$, HEXINHAI $^{1,2}$, LIANGJUNHAO $^{1,2}$, ZHANGZHIYI $^{3}$, ZHANGLIANG $^{1,2}$

${ }^{1}$ Xi'an Polytechnic University, School of Materials Science \& Engineering, Xi'an, 710048, Shaanxi, China

${ }^{2}$ Shaoxing Keqiao West-Tex Textile Industry Innovative Institute, Shaoxing, 312030, Zhejiang, China

${ }^{3}$ Design Institute of Shaanxi Yellow River Group Co. Ltd, Xi'an, 710043, Shaanxi, China

Corresponding author:

HEXINHAI

e-mail: hexinhai@xpu.edu.cn 